\title{
BELAJAR BAHASA INDONESIA MELALUI TEKS BERMUATAN PENDIDIKAN EKOLOGI BERBASIS KEARIFAN LOKAL OSING
}

\author{
Arju Muti'ah; Mujiman Rus Andianto; Parto; Furoidatul Husniah; Akhmad Taufiq; \\ Endang Sri Widayati; Bambang Edi Pornomo; Siswanto; Fitri Nura Murti; Anita Widjajanti; \\ Ahmad Syukron; Arief Rijadi \\ Universitas Jember \\ arju.fkip@unej.ac.id
}

Diterima: 11 Oktober 2018

Publikasi: 27 Februari 2019

DOI: http://dx.doi.org/10.32528/bb.v4i1.1882

\begin{abstract}
ABSTRAK
Pembelajaran bahasa Indonesia berbasis teks memberikan kesempatan kepada peserta didik untuk belajar bahasa Indonesia sekaligus mengembangkan sikap dan perilaku peduli terhadap lingkungan. Melalui metode dokumentasi, tulisan ini disajikan dengan tujuan memaparkan kompetensi pembelajaran bahasa Indonesia berbasis teks di SMP dan mendeskripsikan teks dengan muatan pendidikan lingkungan berbasis kearifan lokal Osing serta penggunaannya dalam pembelajaran. Hasil kajian menunjukkan bahwa terdapat teks bermuatan pendidikan ekologi yang dapat digunakan sebagai sumber materi pembelajaran beragam teks, seperti teks prosedur dan teks fabel. Dari teks-teks tersebut peserta didik, khususnya yang berlatar budaya Osing, dapat dibimbing dalam rangka menguasai kompetensi bahasa serta menumbuhkembangkan sikap dan perilaku peduli terhadap lingkungannya.

Kata Kunci: belajar bahasa Indonesia, teks bermuatan pendidikan ekologi, kearifan lokal Osing
\end{abstract}

\begin{abstract}
Text-based Indonesian learning provides an opportunity for students to learn Indonesian while developing attitudes and caring attitudes towards the environment. Through the documentation method, this paper is presented: first, describing the competency of textbased Indonesian learning in junior high school. Second, describing the text with the content of environmental education based on Osing local wisdom and its use in learning. The results of the study indicate that there are texts containing ecological education that can be used as a source of learning material for various texts, such as procedural texts and fable texts. From these texts, students, especially those who are based on Osing culture, can be guided in order to master language competence and develop caring attitudes and behaviors towards environment.
\end{abstract}

Keywords: learn Indonesian, texts containing ecological education, Osing local wisdom

\section{PENDAHULUAN}

Pembelajaran

bahasa

Indonesia

dilaksanakan dengan tujuan agar para peserta didik memiliki kompetensi keperluan. Hal ini mensyaratkan peserta didik memelajari dan melatih diri dalam berbagai genre yang sesuai dengan tujuan kegiatan sosial dan tujuan komunikasi berbahasa Indonesia untuk berbagai yang memiliki kekhasan cara 
pengungkapan (struktur retorika teks) dan kekhasan unsur kebahasaan. Untuk mencapai tujuan tersebut, pembelajaran bahasa Indonesia di sekolah menengah berfokus pada penyajian beragam teks.

Dalam pandangan pendekatan berbasis genre, sebagaimana dikutip dalam Kemendikbud (2015), teks bukan diartikan semata-mata sebagai tulisan. Teks merupakan kegiatan sosial yang memiliki rtujuan sosial. Terdapat 7 jenis teks sebagai tujuan sosial, yaitu: laporan (report), rekon(recount), eksplanasi (explanation), eksposisi(exposition: discussion, response or review), deskripsi (description), prosedur (procedure), dan narasi (narrative). Lokasi sosial dari eksplanasi dapat berupa berita, ilmiah populer, paparan tentang sesuatu; naratif dapat berupa bercerita, cerita, dan sejenisnya; eksposisi dapat berupa pidato/ceramah (eksemplum ada dalam pidato atau tulisan persuasif), surat pembaca, dan debat. Keberadaan berbagai jenis dan tujuan teks memungkinkan peserta didik mendapatkan pengetahuan bahasa dan pengalaman berbahasa sebagaimana yang terjadi dalam praktik berbahasa seharihari di dalam kehidupan masyarakat. Lebih dari sekedar terampil berbahasa, peserta didik juga dimungkinkan memperoleh wawasan dan beragam kompetensi nonkebahasaan yang berguna bagi kehidupannya.

Beberapa di antara kompetensi nonkebahasaan yang dapat diperoleh siswa dari teks adalah pemahaman lingkungan, pengetahuan tentang fenomena alam, perilaku menjaga dan peduli terhadap lingkungan, serta berbagai pengetahuan, keterampilan, serta sikap positif lainnya sesuai dengan isi dan tujuan teks yang disajikan. Dalam hal ini, selain menjadi bahas ajar bahasa, teks juga menjadi media penyampaian sejumlah pesan pendidikan. Lebih jauh, melalui pembelajaran bahasa berbasis teks ini diharapkan cita-cita menjadikan bahasa Indonesia sebagai penghela dan pembawa ilmu pengetahuan serta sarana pengajaran dan pembiasaan beragam nilai dapat diwujudkan.

Salah satu nilai yang penting dalam kaitannya dengan isu yang mengemuka saat ini adalah nilai kesadaran lingkungan. Masalah lingkungan hidup merupakan fenomena sosial yang memerlukan perhatian khusus dan partisipasi serta tanggung jawab setiap orang. Salah satu hal yang perlu mendapatkan perhatian adalah upaya peningkatan kesadaran dan kepedulian lingkungan melalui penyuluhan, pendidikan, dan penegakan hukum. Kesadaran lingkungan menurut Djaali (1995) meliputi tiga aspek, yakni pengetahuan praktis mengenai masalah lingkungan hidup, sikap berwawasan lingkungan, dan perilaku berwawasan lingkungan.

Nilai kesadaran lingkungan berbasis budaya Osing perlu disampaikan dan diajarkan kepada generasi muda, khususnya para siswa dengan latar belakang budaya tersebut mengingat begitu banyak nilai kearifan lokal dalam aspek lingkungan yang perlu dipertahankan, sementara di sisi lain dengan kencangnya arus informasi mensuplai pesan-pesan yang acapkali 
memiliki dampak jangka panjang dan tidak sesuai dengan nilai-nilai luhur yang ditanamkan oleh para pendahulu. Sebagai contoh, menurunnya praktik penggunaan pranoto mongso yang merupakan sistem kalender musim yang digunakan petani (Jawa) dalam mengatur usaha taninya. Dikemukakan lebih lanjut bahwa sistem tradisional tersebut telah digantikan oleh sistem irigasi teknis yang sayangnya berimplikasi pada biaya yang harus ditanggung petani sebagai kompensasi ketersediaan air di lahan pertaniannya (Hidayati, 2017). Dalam artikelnya tentang pengembangan agrowisata apel, Santoso dan Wikantyoso (2018) menawarkan strategi dalam menghadapi masuknya investor ke pedesaan dengan menyeleksi Investor yang masuk dan program yang direncanakan. Program yang dibawa oleh investor harus sesuai dengan potensi lokal serta mendayagunakan masyarakat sekitar.

Kesadaran lingkungan perlu ditanamkan kepada masyarakat sejak dini. Dalam kaitannya dengan hal tersebut, sekolah memiliki peran strategis sebagai agen pendidikan kesadaran lingkungan bagi para peserta didik. Peran tersebut selanjutnya lebih banyak diiplementasikan melalui kinerja sebgsi fasilitator pembelajaran di kelas. Dengan berlandaskan pada standar kompetensi lulusan yang telah ditetapkan dalam kurikulum, di samping merencanakan tujuan pada ranah pengetahuan dan keterampilan, guru bahasa Indonesia dapat merumuskan serangkaian sikap positif terkait dengan kesadaran terhadap lingkungan, terutama lingkungan tempat peserta didik bermasyarakat dan menjalani kehidupan sehari-harinya.

Dalam penelitiannya tentang strategi pembentukan karakter peduli lingkungan di sebuah sekolah, Al-Anwari (2014) memperoleh informasi bahwa strategi pembentukan karakter peduli lingkungan melalui kegiatan belajar dilakukan dengan dua cara. Pertama, menyajikan mata pelajaran muatan lokal pendidikan lingkungan hidup. Kedua, dengan mengintegrasikan muatan lokal pendidikan lingkungan hidup kedalam seluruh mata pelajaran. Dalam hal ini, teks sebagai materi pembelajaran bahasa Indonesia menjadi salah satu wadah pesan dan nilai kearifan lokal berkaitan sebagaimana dikemukakan oleh Anggraini dan Kusniarti (2017) bahwa isi kearifan lokal dapat dimasukkan dalam teks dan kegiatan siswa, dalam upaya untuk membuatsiswa memahami, baik secara langsung maupun tidak langsung, dan melestarikan kearifan lokal yang ada. Selanjutnya, Kedua strategi tersebut dapat menjadi rujukan bagi penyelenggaraan program pengembangan kesadaran lingkungan yang mengacu pada nilai-nilai yang berkembang di masyarakat dalam hubungannya dengan alam.

Integrasi muatan lokal pendidikan lingkungan hidup ke dalam pembelajaran bahasa Indonesia dapat diimplementasikan melalui penggunaan teks yang memuat tema lingkungan. Melalui teks bertema lingkungan, peserta didik dapat memperoleh wawasan tentang lingkungan, peanfaatan, serta pemeliharaannya, memahami 
Arju Muti'ah, Dkk. Belajar Bahasa Indonesia Melalui Teks bermuatan....

Jurnal Belajar Bahasa, ISSN 2502-5864, E-ISSN 2503-0329

Volume 4, No. 1, Februari 2019

karakteristik beragam teks melalui kegiatan membaca dan mendengarkan, memiliki keterampilan dalam mengomunikasikan pesan tentang lingkungan melalui beragam teks, serta mengasah kepedulian terhadap lingkungan sebagai bagian dari kehidupannya. Pendek kata, melalui teks bertema lingkungan, peserta didik dapat memperoleh kompetensi secara komprehensip yang meliputi kompetensi afektif, kognitif, dan psikomotor. Menurut Rukiyati (2017) membaca buku-buku sastra dan nonsastra dapat menjadi strategi yang ampuh untuk menanamkan nilai-nilai dan moralitas dalam diri peserta didik. Ditegaskan pula dalam temuan penelitian Anggraini dan Kusniarti (2017) bahwa model pembelajaran berbasis kearifan lokal dapat meningkatkan pemahaman dan penguatan karakter peserta didik selama kegiatan pembelajaran di kelas.

Teks bertema lingkungan dinilai dapat mendukung pengembangan karakter peserta didik di sekolah menengah pertama (SMP) dalam berbagai konteks budaya, termasuk budaya masyarakat Osing Banyuwangi. Sebagai generasi penerus, peserta didik memiliki tanggung jawab yang besar dalam menjaga dan melestarikan lingkungan, terutama dimana mereka menetap dan bermasyarakat. Perilaku memperlakukan dan menjaga lingkungan yang telah diterapkan secara turun temurun dalam tradisi masyarakat Osing yang telah terbukti dapat memberikan manfaat kepada masyarakat perlu diajarkan dengan melibatkan lembaga pendidikan formal. Hal ini penting mengingat derasnya arus informasi telah banyak mempengaruhi pola pikir keluarga dan masyarakat Osing sehingga dimungkinkan pendidikan keluarga tidak cukup memberikan perhatian dalam hal pengembangan nilai peduli lingkungan. Lebih-lebih, mata pencaharian penduduk Osing sudah banyak bergeser dari sebagai petani ke profesi lain seperti pedagang, pegawai, pendidik, dan sebagainya.

Artikel ini berisi paparan tentang teks bahasa Indonesia bertema lingkungan berbasis budaya Osing yang berpotensi sebagai sumber belajar bahasa Indonesia untuk sekolah menengah pertama (SMP). Tujuan penulisan artikel ini adalah (1) ) memaparkan kompetensi pembelajaran bahasa Indonesia berbasis teks di SMP, (2) mendeskripsikan teks dengan muatan pendidikan lingkungan berbasis kearifan lokal Osing, dan (3) mendeskripsikan penggunaan teks bermuatan pendidikan lingkungan berbasis kearifan lokal Osing.

\section{METODE}

Informasi yang dipaparkan dalam artikel ini diperoleh melalui kajian berbagai sumber yang memuat informasi tentang kompetensi pembelajaran bahasa Indonesia, ragam teks, kearifan lokal, dan pendidikan berbasis ekologi, baik dalam format cetak maupun digital. Kajian diarahkan pada upaya mengidentifikasi dan menemukan teks bertema ekologi dengan latar belakang budaya Osing yang berpotensi menjadi sumber belajar bahasa Indonesia. Selanjutnya, dilakukan proses adaptasi teks dengan memperhatikan kriteria aspek isi, struktur, 
Arju Muti'ah, Dkk. Belajar Bahasa Indonesia Melalui Teks bermuatan....

Jurnal Belajar Bahasa, ISSN 2502-5864, E-ISSN 2503-0329

Volume 4, No. 1, Februari 2019

dan ciri kebahasaan setiap jenis teks sesuai dengan kebutuhan kompetensi yang terdapat dalam kurikulum bahasa Indonesia kelas I SMP.

\section{HASIL DAN PEMBAHASAN}

Kompetensi dalam Pembelajaran Bahasa Indonesia SMP

Pembelajaran bahasa indonesia di kelas VII SMP dilaksanakan untuk mencapai seperangkat kompetensi sebagaimana terdapat dalam Permenfikbud Nomor 24 Tahun 2018. Kompetensi inti untuk kelas VII adalah sebagai berikut.

(1) Memiliki perilaku yang mencerminkan sikap:beriman dan bertakwa kepada Tuhan YME, berkarakter, jujur, dan peduli, bertanggungjawab, pembelajar sejati sepanjang hayat, dan sehat jasmani dan rohani sesuai dengan perkembangan anak di lingkungan keluarga, sekolah, masyarakat dan lingkungan alam sekitar, bangsa, negara, dan kawasan regional.

(2) Memahami pengetahuan (faktual, konseptual, dan prosedural) berdasarkan rasa ingin tahunya tentang ilmu pengetahuan, teknologi, seni, budaya terkait fenomena dan kejadian tampak mata.

(3) Mencoba, mengolah, dan menyaji dalam ranah konkret (menggunakan, mengurai, merangkai, memodifikasi, dan membuat) dan ranah abstrak (menulis, membaca, menghitung, menggambar, dan mengarang) sesuai dengan yang dipelajari di sekolah dan

sumber lain yang sama dalam sudut pandang/teori.

Kompetensi pada butir (1) menuat aspek sikap, butir (2) mdmuat aspek pengetahuan, dan butir (3) memuat aspek keterampilan. Berbagai karakter positif yang dikembangkan, diharapkan dapat diterapkan dalam berbagai lingkup, termasuk dalam lingkungan masyarakat dan alam sekitar. Dalamhubungannya dengan alsm sekitar, peserta didik diharapkan memiliki sikap pddjli dan bertanggung jawb dalam merawat dan menjaga lingkungan sebagai bahan dari upaya sinergis antara pemanfaatan dan peestarian lingkungan. Pengembsngan kompetensi sikap tersebut diintegrasikan ke dalam pembelsjan untuk mencapai kompetensi butir (2) dan (3).

Kompetensi-kompetensi tersebut selanjutnya dijabarkan ke dalam kompetensi yang lebih spesifik. Mompetensi pada level ini disebut sebagai kompetensi dasar (KD). Kompetensi dasar mata pelajaran bahasa Indonesia kelas VII mencakup kompetensi aspek kognitif dan psikomotor yang mengarah pada penguasaan beragam teks yang meliputi teks deskripsi, teks cerita fantasi, teks prosedur, teks laporan hasil observasi, surat dinas dan surat pribadi, teks puisi rakyat, teks fabel, serta buku fiksi dan nonfiksi. Berbagai teks tersebut disajikan kepada siswa sesusi dengan kebutuhan penggunaannya dalam praktik berkomunikasi. Secara rinci kompetensi kognitif dan psikomotor tersebut adalah sebagai berikut. 
Arju Muti'ah, Dkk. Belajar Bahasa Indonesia Melalui Teks bermuatan....

Jurnal Belajar Bahasa, ISSN 2502-5864, E-ISSN 2503-0329

Volume 4, No. 1, Februari 2019

\section{Ranah Kognitif}

3.1 Mengidentifikasi informasi dalam teks deskripsi tentang objek (sekolah, tempat wisata, tempat bersejarah, dan atau suasana pentas seni daerah) yang didengar dan dibaca

3.2 Menelaah struktur dan kebahasaan dari teks deskripsi tentang objek (sekolah, tempat wisata, tempat bersejarah, danatau suasana pentas seni daerah) yang didengar dan dibaca

3.3 Mengidentifikasi unsur-unsur teks narasi (cerita imajinasi) yang dibaca dan didengar

3.4 Menelaah struktur dan kebahasaan teks narasi (cerita imajinasi) yang dibaca dan didengar

3.5 Mengidentifikasi teks prosedur tentang cara melakukan sesuatu dan cara membuat (cara memainkan alat musik/tarian daerah, cara membuat kuliner khas daerah, dll.) dari berbagai sumber yang dibaca dan didengar

3.6 Menelaah struktur dan aspek kebahasaan teks prosedur tentang cara melakukan sesuatu dan cara membuat (cara memainkan alat musik/tarian daerah, cara membuat kuliner khas daerah, dll.) dari berbagai sumber yang dibaca dan didengar

3.7 Mengidentifikasi informasi dari teks laporan hasil observasi berupa buku pengetahuan yang dibaca atau diperdengarkan

3.8 Menelaah struktur, kebahasaan, dan isi teks laporan hasil observasi yang berupa buku pengetahuan yang dibaca atau diperdengarkan

3.9 Menemukan unsur-unsur dari buku fiksi dan nonfiksi yang dibaca

3.10 Menelaah hubungan unsur-unsur dalam buku fiksi dan nonfiksi

3.11 Mengidentifikasi informasi (kabar, keperluan, permintaan, dan/atau permohonan) dari surat pribadi dan surat dinas yang dibaca dan didengar

3.12 Menelaah unsur-unsur dan kebahasaan dari surat pribadi dan surat dinas yang dibaca dandidengar

3.13 Mengidentifikasi informasi (pesan, rima, dan pilihan kata) dari puisi rakyat (pantun, syair, dan bentuk puisi rakyat setempat) yang dibaca dan didengar

3.14 Menelaah struktur dan kebahasaan puisi rakyat (pantun, syair, dan bentuk puisi rakyat setempat) yang dibaca dan didengar

3.15 Mengidentifikasi informasi tentang fabel/legenda daerah setempat yang dibaca dan didengr.

3.16 Menelaah struktur dan kebahasaan fabel/legenda daerah setempat yang dibaca dan didengar.

\section{Ranah Psikomotor}

4.1 Menjelaskan isi teks deskripsi objek (tempat wisata, tempat bersejarah, pentas seni daerah, kain tradisional, dII) yang didengar dan dibaca secara lisan, tulis, dan visual

4.2 Menyajikan data, gagasan, kesan dalam bentuk teks deskripsi tentang objek (sekolah, tempat wisata, 
Arju Muti'ah, Dkk. Belajar Bahasa Indonesia Melalui Teks bermuatan....

Jurnal Belajar Bahasa, ISSN 2502-5864, E-ISSN 2503-0329

Volume 4, No. 1, Februari 2019

tempat bersejarah, danatau suasana pentas seni daerah) secara tulis dan lisan dengan memperhatikan struktur, kebahasaan baik secara lisan maupun tulis

4.3 Menceritakan kembali isi teks narasi (cerita imajinasi) yang didengar dan dibaca secara lisan, tulis, dan visual

4.4 Menyajikan gagasan kreatif dalam bentuk cerita imajinasi secara lisan dan tulis dengan memperhatikan struktur, penggunaan bahasa, atau aspek lisan

4.5 Menyimpulkan isi teks prosedur tentang cara memainkan alat musik daerah, tarian daerah, cara membuat cinderamata, dan/atau kuliner khas daerah) yang dibaca dan didengar

4.6 Menyajikan data rangkaian kegiatan ke dalam bentuk teks prosedur (tentang cara memainkan alat musik daerah, tarian daerah, cara membuat cinderamata, dll) dengan memperhatikan struktur, unsur kebahasaan, dan isi secara lisan dan tulis

4.7 Menyimpulkan isi teks laporan hasil observasi berupa buku pengetahuan yang dibaca dan didengar

4.8 Menyajikan rangkuman teks laporan hasil observasi yang berupa buku pengetahuan secara lisan dan tulis dengan memperhatikan kaidah kebahasaan atau aspek lisan

4.9 Membuat peta pikiran/sinopsis tentang isi buku nonfiksi/buku fiksi yang dibaca
4.10 Menyajikan tanggapan secaralisan, tulis, dan visualterhadap isi buku fiksi/nonfiksi yang dibaca

4.11 Menyimpulkan isi (kabar, keperluan, permintaan, dan/atau permohonan) surat pribadi dan surat dinas yang dibaca atau diperdengarkan

4.12 (pribadi dan dinas) untuk kepentingan resmi dengan memperhatikan struktur teks, kebahasaan, dan isi

4.13 Menyimpulkan isi puisi rakyat (pantun, syair, dan bentuk puisi rakyat setempat) yang disajikan dalam bentuk tulis dan lisan

4.14 Menelaah struktur dan kebahasaan puisi rakyat (pantun, syair, dan bentuk puisi rakyat setempat) yang dibaca dan didengar

4.15 Menceritakan kembali isi cerita fabel/legenda daerah setempat yang dibaca/didengar

4.16 Memerankan isi fabel/legenda daerah setempat yang dibaca dan didengar.

Jika diperhatikan, rumusan kompetensi di atas menberikan peluang kepada guru untuk menyajikan teks bertema ekologi untuk menguatkan karakter cinta fan peduli lingkungan di samping mengembangkan penguasaan beragam teks tersebut sebagai bentuk komunikasi. Pembelajaran teks deskripsi, misalnya, diarahkan pada deskripsi tempat wisata, tempat bersejarah, kain tradisional, dan lain-lain yang bermuatan tema ekologi atau dapat diberi muatan tema ekologi. Demikian juga dengan jenis teks lainnya. Pendek kata, semua kompetensi yang dipaparkan, baik yang mengacu pada 
Arju Muti'ah, Dkk. Belajar Bahasa Indonesia Melalui Teks bermuatan....

Jurnal Belajar Bahasa, ISSN 2502-5864, E-ISSN 2503-0329

Volume 4, No. 1, Februari 2019

penguasaan teks nonsastra maupun teks sastra, teks nonfiksi maupun teks fiksi dapat memuat tema-tema ekologi.

\section{Teks Bermuatan Pendidikan Lingkungan}

\section{Berbasis Kearifan Lokal Osing}

Secara umum teks dapat dikatakan sebagai wujud penggunaan bahasa dalam komunikasi. Glosari istilah linguistik SIL merumuskan Teks sebagai rangkaian paragraf yang merepresentasikan unit pembicaraan yang luas. Jika rumusan di atas kebih berfokus pada bentu linguistiknya, Kemendikbud, ( 2015) lebih memberikan tekanan pada aspek fungsi dengan penegasan bahwa Teks merupakan kegiatan sosial yang memiliki tujuan sosial.

Sejalan dengan fungsi sosial teks, Mickan (2015) memberikan ilustrasi dengan nenyatakan bahwa kita hidup dengan bahasa sebagai teks, bukan sebagai daftar kosakataitem atau tata bahasa, kita akrab dengan banyak teks, kitai menggunakan teks setiap hari untuk banyak tujuan yang berbeda, kita bersenang-senang dengan teks, kita membuat dan memutuskan hubungan dengan teks, kita mendapat pekerjaan dan tugas dilakukan dengan teks, kita merekam dan menghubungkan pengalaman dengan teks. Kita membuat perjanjian dengan teks. Kita melewatkan waktu kitai dalam percakapan - dengan teks, kita menghormati orang dengan teks, kita menghina orang dengan teks, kita berperang dan berdamai dengan teks.

Sebagai wujud kegiatan sosial, teks memiliki muatan yang beragam, termasuk tema-tema ekologi. Teks bermuatan tema ekologi dapat berisi paparan tentang objek lingkungan alam, termasuk kehidupan sosial di dalamnya, kekayaan alam, pemanfaatan sumberdaya alam, serta pernasalahan lingkungan. Kenyataan ini menyebabkan teks dengan muatan tema ekologi fapat memberikan sumbangsn ysng besar bagi pengembangan kompetensi berbahasa dan sikap peduli lingkungan.

Pengembangan kompetensi berbahasa dan sikap peduli lingkungan pada anakanak dengan latar budaya Osing dapat ditempuh melalui penyajian beragam teks dengan muatan tema ekologi berbasis kearifan lokal Osing. Dengan demikian, diharapkan pada diri setiap siswa akan tumbuh dan berkembang kemampuan berbahasa Indonesia, sekaligus sikap dan peerilaku peduli terhadap lingkungannya. Dalam kaitannya dengan hal tersebut, Armawi (2017) menyatakan bahwanilai etis yang didasarkan pada kearifan manusia dan kearifan lokal juga penting diperhatikan, agar tidak terjadi penolakanpenolakan dan konflik antarunsur ekologi dalam suatu ekosistem,sehingga terjadi interaksi yang harmoni dan seimbang antara pemanfaatan dan pemeliharaan sumberdaya alam. Sejalan dengan itu, sekolah adalah tempat yang lebih baik. Tentunya lebih kondusif untuk belajar dan mengajar Lembaga ini memiliki tanggung jawab menyampaikan dan mengajarkan nilai-nilai yang menjadi dasar karakter yang baik (Lickona, 2006).

Berikut, beberapa contoh teks dengan muatan ekologi berbasis kearifan lokal Osing baik yang diadaptasi dari sumber tertentu maupun yang dikreasikan dengan 
Jurnal Belajar Bahasa, ISSN 2502-5864, E-ISSN 2503-0329

Volume 4, No. 1, Februari 2019

memanfaatkan aspek-aspek kearifan lokal Osing.

\section{(1) Membuat Ancak}

Makan makanan dalam satu wadah secara bersama-sama di tempat tertentu seperti depan rumah atau pinggir jalan desa, tempat belajar mengaji, masjid, atau tempat-tempat lain merupakan budaya sebagian masyarakat Indonesia. Di Sumatera, Jawa, dan Madura budaya ini dikenal di masyarakat dalam acara keagamaan Islam seperti Maulud Nabi, Hari Raya Idul Fitri/ Idul Adha, Isra Miraj, dan acara-acara lain. Di Banyuwangi, di samping pada peringatan keagamaan, makan bersama dalam satu wadah selalu dilakukan masyarakat dalam acara bersih desa setelah perayaan ider bumi.

Keunikan acara makan bersama di Banyuwangi adalah wadah atau tempat makanan yang masih menggunakan bahan tradisional yang tidak dijumpai lagi di kota. Wadah makanan tersebut disebut ancak.

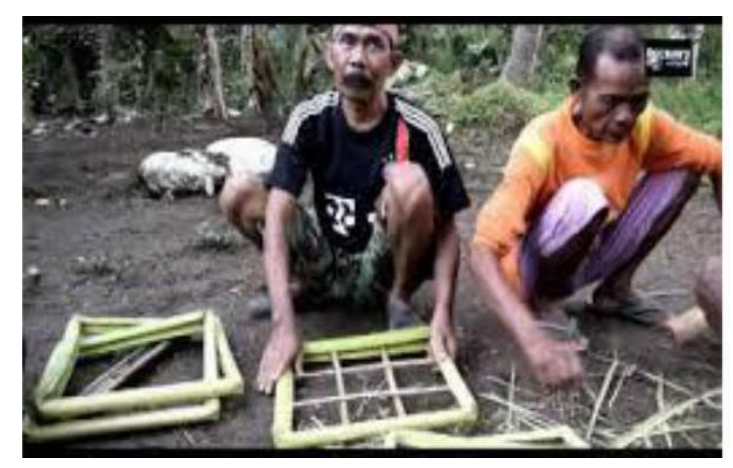

Gambar 1. Membuat Ancak

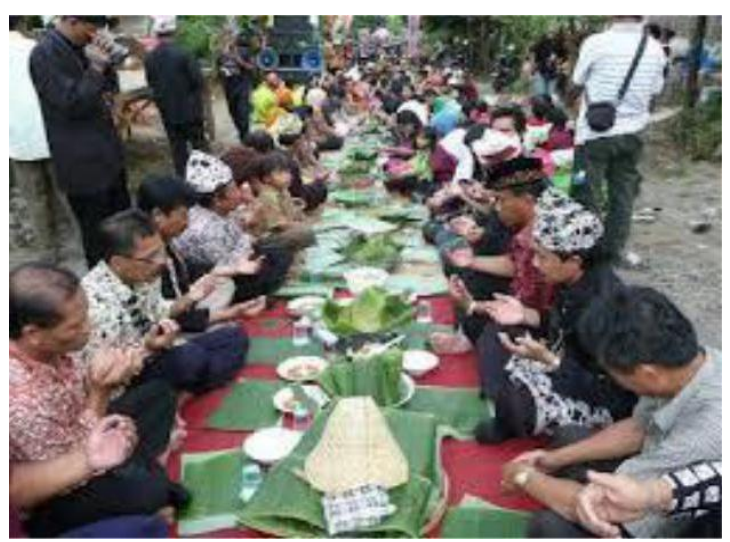

Gambar 2. Budaya Makan Bersama Memakai Ancak

Ingin tahu cara membuatnya? Berikut ini cara membuat ancak.

Pertama, perlu kita siapkan bahan bahan dan alatnya. Bahan dan alatnya sebagai berikiut:

a. dua batang daun pisang yang sudah dijemur beberapa saat

b. daun pisang

c. bambu yang sudah dipotong seperti pensil ukuran $10 \mathrm{~cm}$

d. bambu tipis dengan lebar $1,5 \mathrm{~cm}$ dan panjang $30 \mathrm{~cm}$ sebanyak 6 batang, lancipkan ujungnya

e. stik lidi atau semat lidi (terbuat dari lidi yang dipotong serong agar lancip sepanjang 7 atau $8 \mathrm{~cm}$, sebanyak 6 buah.

f. gunting

g. pisau.

Cara membuat ancak relatif mudah. Pertama, pisahkan daun dari batang pisang dengan pisau. Pastikan pisau yang digunakan cukup tajam agar menghasilkan potongan yang rapi. Setelah itu, tekuk kedua batang daun pisang menjadi persegi (bujur sangkar) lalu rapatkan salah satu ujungnya yang terpisah dengan bambu serupa pencil $10 \mathrm{~cm}$. Terbentuklah kotak atau persegi dari batang daun pisang. Lalu, 
isi bagian dalam kotak yang kosong dengan bambu tipis yang panjangnya 30 $\mathrm{cm}$. Pasangkan secara vertikal 3 batang dan horizontal 3 batang membentuk anyaman lebar. Dengan demikian, isi kotak batang daun pisang kini sudah memiliki alas bambu.

Siapkan daun pisang yang sudah tidak terlalu keras, lap dengan lap bersih atau tisu bagian dalam dan luar. Rekatkanlah daun pisang tersebut denga posisi luar (yang berwarna lebih tua) berada di luar dengan semat lidi. Daun yang sudah direkatkan tersebut akan digunakan untuk menjadi alas di atas anyaman bambu ancak. Sesuaikan ukuran daun yang disemat lidi dengan luas ancak. Penuhi alas ancak dengan daun yang direkat semat dengan rapi pada bagian pinggir dan tengah. Jadilah ancak yang siap digunakan untuk wadah nasi. Cara melatakkan makana di ancak dilakukan dengan meletakkan nasi di seluruh ancak lalu menata lauk dan sayur secara rapi di tiap bagian di atas nasi. Tutup makanan di wadah ancak dengan daun pisang yang tersisa dan rekatkan tutup daun tersebut dengan semat lidi. Ancak siap dibawa untuk acara makan bersama.

\section{(2) Petualangan Pertama di Alam Bebas}

Di Desa Alas malang nan tentram, terdapat sebuah kandang yang cukup bersih. Di kandang tersebut dihuni oleh segerombolan kerbau jantan dan betina. Kerbau betina sedang dalam kondisi bunting dan akan segera melahirkan. Kerbau jantan gelisah untuk menunggu kelahiran anak-anak mereka, sehingga dalam kegelisahannya ada perasaan ketakutan yang tidak jelas apakah sebabnya.

Malam datang, terdengar lolongan serigala yang mencekam, seakan-akan tahu kalau kerbau betina akan melahirkan. Kerbau jantan berusaha menenangkan diri dengan berjalan mondar-mandir di kandangnya. Tibalah saatnya kerbau betina berjuang keras melahirkan anakanaknya, akhirnya lahirlah empat anak kerbau yang semuanya dalam kondisi sehat. "Syukurlah Mbok...anak-anak kita lahir selamat." lya...pak..di beri nama siapa ya? tanya kerbau betina. Kalau begitu diberi nama batu loso, batu naga, batu gajah, dan batu karangan. "Bagaimana cara menandainya pak?"tanya kerbau betina. "Batu loso anak pertama yang agak kurus mbok.., batu naga anak kedua yang punya tanda tubuh agak panjang, batu gajah anak ketiga yang memiliki tubuh amat besar, dan batu karangan anak keempat yang punya tubuh lebar," jawab kerbau jantan sembari mengelus empat anaknya yang terlelap tidur.

"Loso, naga, gajah, karangan, ayo bangun jangan malas...segera berangkat ikuti ayahmu untuk cari makanan di kebun desa Alas malang."

"Ya mbok.....jawab mereka serentak tak membantah sedikitpun."

"Aku pamit ya mbok.."kata kerbau jantan. "Ya ati-ati pak...anak-anak aharus diawasi karena mereka belum tahu arah..apalagi keadaan kebun di desa Alas malang masih banyak hewan buas dan jurang terjal" . Ya aku tahu...tapi kalau tidak diajak mereka nanti tidak bisa merumput sendiri. kerbau 
Arju Muti'ah, Dkk. Belajar Bahasa Indonesia Melalui Teks bermuatan....

Jurnal Belajar Bahasa, ISSN 2502-5864, E-ISSN 2503-0329

Volume 4, No. 1, Februari 2019

jantan berjalan beriringan dengan

Dengan badan lunglai dan cemas keempat anaknya menuju kebun yang agak jauh dari kandangnya.

Tibalah mereka berlima di sebuah kebun yang sangat lebat rumputnya. Loso, naga, gajah, dan karangan berlari kegirangan. kerbau jantan sampai di kandang dan menceritakan atas petaka yang menimpa keempat anaknya. Kerbau betina menangis sejadi-jadinya memanggil anakanaknya.

"Loso......naga,...., gajah.....,

"Hore...Pak, pasti aku kenyang" ..ujar karangan........dimana anak-anakku.." loso. "Meskipun kenyang badanmu tetap kurus"...ujar gajah.

Mereka bercanda sepuasnya sembari memakan rumput yang ada di sekitaranya. Kerbau jantan datang dan mengingatkan anak-anaknya untuk tidak berlebihan mencari makan, jangan terpisah-pisah karena banyak hewan buas dan jurang yang terjal. Sepertinya anak-anak kerbau jantan tidak menghiraukan peringatannya. Mereka asyik makan dan bercanda dan sangat gembira karena baru pertama kali di ajak keluar dan melihat dunia luar.

Hari mulai terik..kerbau jantan memanggil anak-anaknya untuk mencari sungai.

"ayo kita pergi mencari sungai di dekat sini..kita mandi. Ikuti aku anak-anakku" sembari berjalan

Loso, naga, gajah, dan karangan berjalan dibelakang kerbau jantan. Tiba-tiba loso melihat ada ular yang berada di bawah kakinya. Loso berteriak sembari berlari, Sontak ketiga anaknya lari berhamburan ke segala arah. Loso ke arah timur, naga berlari ke arah barat, gajah berlari ke arah selatan, dan gajah berlari ke arah utara. Kerbau jantan berteriak-teriak memanggil anaknya sampai petang tiba. Akhirnya kerbau jantan memutuskan pulang ke kandang.

"Perasaanku tadi sudah tidak enak......apakah mereka terperosok ke jurang atau dimakan oleh

harimau.....pikiran kerbau betina menjadi tidak karuan."

Itulah hal yang pernah kerbau jantan takutkan saat menyambut kelahiran keempat anaknya.

Ternyata ini jawabannya....

Pagi telah tiba, kerbau jantan dan kerbau betina bergegas keluar kandang menuju ke kebun dan tempat saat kerbau jantan berpisah dengan anak-anaknya. Kerbau jantan berteriak memanggil anaknya menuju ke arah utara dan selatan, sedangkan kerbau betina menuju ke arah timur dan barat. Kerbau betina menangis dan berlari tak tentu arah. Tanpa sengaja ia tersandung tulang belulang hewan yang telah dimakan binatang buas. Kerbau betina tersentak kaget dan berteriak memanggil kerbau jantan.

"Kesinilah.....ini pasti anak-anakmu..."

Seru kerbau betina.

Kerbau jantan meloncat dan mulai melototi tulang-tulang yang berserakan. "bukan mbok....ini bukan tulang anakanak kita...aku yakin, anak-anak kita pasti masih di sekitar sini". 
Arju Muti'ah, Dkk. Belajar Bahasa Indonesia Melalui Teks bermuatan....

Jurnal Belajar Bahasa, ISSN 2502-5864, E-ISSN 2503-0329

Volume 4, No. 1, Februari 2019

Loso... naga.....di mana kamu

nak....gajah,,,,, karangan,,,,,,, dimana

kamu nak

Sampai di suatu tempat dan matahari siang sangat terik, kerbau jantan dan kerbau betina tidak lelah berteriak memanggil anak-anaknya. Hingga lelahlah mereka dan bernaung di bawah sebuah pohon. Tiba-tiba kerbau betina mendengar rintihan kesakitan dari berbagai arah. Kerbau betina bergegas berlari dan menghampiri dari sumber suara yang didengarnya. Akhirnya kerbau jantan dan betina berhasil menemukan anak-anaknya dalam keadaan pingsan dan terluka. Diputuskanlah bahwa untuk tidak membawa anak-anaknya keluar kandang karena usianya yang masih kecil dan terlalu berisiko untuk berhadapan dengan alam luar. Cukuplah berada di dalam kandang di desa Alas malng yang tentram dan damai.

Kedua teks di atas sama-sama memuat pesan terkait dengan lingkungan. Teks pertama adalah jenis teks prosedur yang bertujuan memberikan petunjuk kepada pembaca tentang langkah-lanhkah membuat ancak, wadah makanan yang biasa digunakan masyarakat Banyuwangi, termasuk masyarakat Osing untuk acara makan bersama. Dari teks tersebut diketahui bahwa ancak terbuat dari bambu dan daun pisang. Bahan ini adalah bahan alami yang diperoleh dari lingkungan sekitar. Biomaterial ini tidak berpitensi mencemari lingkungan. Hal ini tentu berbeda dengan wadah makanan yang terbuat dari plastik atau bahan nonalamiah lain. Di samping manfaat, terutama dari segi kepraktisannya, bahan

-bahan tersebut menjadi salah satu sumber permasalahan pencemaran lingkungan yang cukup mengkhawatirkan. Teks kedua, menonjolkan latar pedesaan dan areal hutan yang asri. Digambarkan areal dengan rumput yang menghijau dan subur. Ini merupakan sumber makanan yang melimpah bagi hewan piaraan. Dalam cerita ini digambarkan pula kandang kerbau yang bersih dan rapi. Hal tersebut mengisyaratkan pemiliknya selalu membersihkandan menata kandang untuk menjaga kebersihan dan kerapian lingkungan. Terdapat pesan pendidikan lingkungan untuk selalu menjaga dan melestarikan lingkungan alam, baik vegetasi maupun pemukiman penduduk.

\section{Penggunaan Teks Bermuatan Pendidikan Lingkungan Berbasis Kearifan Lokal Osing}

Sejak tahun 1960-an pengajaran bahasa telah berubah sebagai tanggapan terhadap kebutuhan untuk mendesain ulang pembelajaran untuk mencapai tujuan komunikatif.. Dengan komunikasi sebagaitujuan pembelajaran, pendekatan struktural dinilai tidak dapat memenuhi kebutuhan.. Pendekatan struktural mengajarkan aspek-aspek bahasa secara terpisah dari teks. Sementara itu, integrasi antara aspek kebahasa dengan konteks yang mewujudkan teks merupakan kebutuhan pembelajaran yang berorientasi pada pembentukan kompetensi komunikatif. Paradigma ini sejalan dengan pendekatan whole language dan pendekatan CLIL. Pendekatan whole language memandang bahasa sebagai suatu kesatuan yang 
memuat unsur simbol, sistem, dan konteks (Goodman, 2005). Ketiga unsur tersebut terintegrasi dan membentuk bahasa dengan berbagai fungsinya sebagaimana ditemukan dalam penggunaannya oleh masyarakat. Kondisi tersebut melahirkan beragam teks dengan fungsi sosialnya masing - masing. Sementara itu, pendekatan CLIL melihat teks sebagai wadah informasi kebahasaan dan nonkebahasaan yang dapat memfasilitasi siswa dalam belajar bahasa sekaligus belajar isi atau konten yang dimuat di dalam teks. Coyle (2007) mengajukan $4 \mathrm{C}$ sebagai penerapan CLIL, yaitu content, communication, cognition, culture (community/citizenship). Content berkaitan dengan topik atau tema, seperti ekosistem dan budaya Kedua pendekatan tersebut dapat mengakomodasi kebutuhan pembelajaran bahasa Indonesia yang menempatkan lingkungan sebagai bagian dari kehidupan manusia dengan peran dan posisinya yang strategis.

Berikut ini adalah gambaran penggunaan teks dengan muatan pendidikan ekologi berlatar belakang kearifan lokal Osing. Ilustrasi ini menggunakan kelas VII sebagai konteks dengan kompetendi inti aspek afekyif dan kognitif sebagai acuannya.

Kompetensi inti aspek afektif: Menunjukkan perilaku jujur, disiplin, tanggung jawab, peduli (toleransi, gotong royong), santun, dan percaya diri dalam berinteraksi secara efektif dengan lingkungan sosial dan alam dalam jangkauan pergaulan dan keberadaannya".
Kompetensi inti aspek kognitif: memahami pengetahuan faktual, konseptual dan prosedural berdasarkan rasa ingin tahunya tentang ilmu pengetahuan, teknologi dan seni budaya terkait fenomena dan kejadian tampak mata.

Kompetensi dasar yang diangkat adalah kompetensi buyir 3.6: menelaah struktur dan aspek kebahasaan teks prosedur tentang cara melakukan sesuatu dan cara membuat (cara memainkan alat musik/tarian daerah, cara membuat kuliner khas daerah, dII.) dari berbagai sumber yang dibaca dan didengar.

Selanjutnya, dari kompetensikompetensi tersebut, dirumuskan indikator-indikator berikut.

\section{Indikator}

1) Memiliki sikap peduli terhadap lingkungan yang ditunjukkan oleh isi pernyataan yang dibuat terkait dengan permasalahan lingkungan.

2) Mengidentifikasi struktur teks prosedur melalui teks prosedur yang dibaca.

3) Menjelaskan struktur teks prosedur beserta bagian-bagiannya.

4) Mengidentifikasi ciri bahasa (kata baku, kalimat perintah, kalimat saran, kalimat larangan) pada teks prosedur yang dibaca.

5) Menjelaskan ciri bahasa teks prosedur.

6) Mengurutkan teks prosedur yang rancu sesuai dengan struktur yang benar.

7) Menemukan kesalahan penggunaan bahasa dalam teks prosedur. 
Arju Muti'ah, Dkk. Belajar Bahasa Indonesia Melalui Teks bermuatan....

Jurnal Belajar Bahasa, ISSN 2502-5864, E-ISSN 2503-0329

Volume 4, No. 1, Februari 2019

8) Merevisi kesalahan penggunaan bahasa yang ditemukan dalam teks prosedur.

Untuk membantu peserta didik mencapai kompetensi sebagaimana disebutkan dalam indikator, digunakan teks prosedur yang terdapat pada subbab berikutnya sebagai sumber sekaligus bahan ajar.

Sebelum masuk ke bagian inti pembelajaran, dapat ditampilkan video yang berhubungan dengan isi teks yang akan dipelajari. Hal ini dimaksudkan sebagai upaya membangun kontrks agar peserta didik memperoleh gambaran awal tentang fokus pembelajaran sekaligus memahami pentingnya pembelajaran tersebut bagi kehidupannya di tengah masyarakat.

Kegiatan pembelajaran akan didominasi oleh aktivitas membaca dan diskusi. Peserta didik diarahkan untuk membaca dan mengidentifikasi isi setiap bagian teks. Guru bisa menggunakan warna atau simbol lain sebagai penanda bagian-bagian yang berbeda untuk membantu peserta didik dalam menemukan isi setiap bagian sebagai acuan dslam menentukan struktur teks prosedur.

\section{Membuat Ancak}

Masyarakat Banyuwangi, memiliki kebiasaan makan bersama pada acaraacara tertentu, seperti peringatan Maulid Nabi dan acara bersih desa setelah perayaan ider bumi. Acara makan berssma tersebut termasuk unik karena menggunakan wada ysng khas dsn terbuut dari bahan alam. Wadah makanan tersebut dinamakan ancak. Ingin tahu cara membuatnya? Berikut ini dipaparkan cara membuat ancak.

Pertama, perlu kita siapkan bahan bahan dan alatnya. Bahan dan alatnya sebagai berikut:

a. dua batang daun pisang yang sudah dijemur beberapa saat

b. daun pisang

c. bambu yang sudah dipotong seperti pensil ukuran $10 \mathrm{~cm}$

d. bambu tipis dengan lebar $1,5 \mathrm{~cm}$ dan panjang $30 \mathrm{~cm}$ sebanyak 6 batang, lancipkan ujungnya

e. stik lidi atau semat lidi (terbuat dari lidi yang dipotong serong agar lancip sepanjang 7 atau $8 \mathrm{~cm}$, sebanyak 6 buah.

f. gunting

g. pisau

Cara membuat ancak relatif mudah. Pertama, pisahkan daun dari batang pisang dengan pisau. Pastikan pisau yang digunakan cukup tajam agar menghasilkan potongan yang rapi. Setelah itu, tekuk kedua batang daun pisang menjadi persegi (bujur sangkar) lalu rapatkan salah satu ujungnya yang terpisah dengan bambu serupa pencil $10 \mathrm{~cm}$. Terbentuklah kotak atau persegi dari batang daun pisang. Lalu, isi bagian dalam kotak yang kosong dengan bambu tipis yang panjangnya 30 $\mathrm{cm}$. Pasangkan secara vertikal 3 batang dan horizontal 3 batang membentuk anyaman lebar. Dengan demikian, isi kotak batang daun pisang kini sudah memiliki alas bambu.

Siapkan daun pisang yang sudah tidak terlalu keras, lap dengan lap bersih atau tisu bagian dalam dan luar. Rekatkanlah 
daun pisang tersebut denga posisi luar (yang berwarna lebih tua) berada di luar dengan semat lidi. Daun yang sudah direkatkan tersebut akan digunakan untuk menjadi alas di atas anyaman bambu ancak. Sesuaikan ukuran daun yang disemat lidi dengan luas ancak. Penuhi alas ancak dengan daun yang direkat semat dengan rapi pada bagian pinggir dan tengah. Jadilah ancak yang siap digunakan untuk wadah nasi. Cara melatakkan makana di ancak dilakukan dengan meletakkan nasi di seluruh ancak lalu menata lauk dan sayur secara rapi di tiap bagian di atas nasi. Tutup makanan di wadah ancak dengan daun pisang yang tersisa dan rekatkan tutup daun tersebut dengan semat lidi. Ancak siap dibawa untuk acara makan bersama.

Peserta didik dapat diberi pertanyaanpertanyaan yang bersifat menuntun yang mengarahkan mereka kepada struktur teks di atas. Pertanyaan tersebut, misalnya, bagian pertama teks tersebut berisi apa, apa yang disampaikan pada bagian berikutnya, setelah bahan dan alat, apa yang dipaparkan, dan bagian akhir berisi apa. Berdasarkan jawaban peserta didik, guru memberikan penegasan bahwa struktur teks prosedur meliputi tujuan, bahan dan alat, langkah, dan penutup. Setelah memperoleh informasi tentang struktur teks prosedur, peserta didik diajak untuk mengambil pelajaran dari isi teks yang dipelajari. Melalui tanya jawab dan penugasan, peserta didik menyampaikan pendapat dan persepsinya terkait pemanfaatan bahan alam oleh masyarakat. Hal ini dimaksudkan sebagai upaya mengembangkan sikap peduli terhadap lingkungan sebagai salah satu karakter yang diharapkan akan dimiliki oleh peserta didik.

Pemahaman ciri kebahasaan teks prosedur dapat dimiliki peserta didik dengan cara mengarahkan mereka untuk membaca dan memberikan tanda pada kata-kata atau kalimat yang serupa dan cenderung berulang. Dari data yang ditemukan, peserta didik melalui bimbingan guru, menyatakan ciri kebahasaan yang membedakan teks prosedur dengan jenis teks lain. Penguatan pemahaman struktur dan ciri kebahasaan teks prosedur dapat dilakukan melalui penyajian teks prosedur yang diacak dan penyajian teks yang memuat kesalahan penggunaan bahasa. Peserta didik diarahkan untuk menata atau mengurutkan bagian-bagian teks sehingga menjadi teks prosedur yang sistematis. Peserta didik juga diarahkan untuk menemukan kesalahan penggunaan bahasa, kemudian merevisinya sehingga menjadi teks prosedur yang mudah dipahami.

Gambaran singkat tentang penggunaan teks prosedur di atas, menunjukkan bahwa peserta didik dapat belajar struktur dan ciri kebahasaan teks prosedur, sekaligus memperoleh pemahaman tentang cara membuat wadah makanan yang ramah lingkungan karena terbuat dari bahan alam. Lebih dari itu, mereka juga dapat memperoleh wawasan dan nembangun kesadaran tentang nila-nilai positif yang telah tertanam dalam tradisi masyarakat dan diwariskan secara turuntemurun. Dengan demikian, diharapkan akan tumbuh sikap peduli terhadap 
Arju Muti'ah, Dkk. Belajar Bahasa Indonesia Melalui Teks bermuatan....

Jurnal Belajar Bahasa, ISSN 2502-5864, E-ISSN 2503-0329

Volume 4, No. 1, Februari 2019

lingkungan sebagai wujud tanggung jawab yang harus diemban generasi penerus.

\section{SIMPULAN}

Bahasa Indonesia, sebagai lambang identitas sekaligus sarana komunikasi dalam lingkup nadional perlu dijaga dan dipelajari setiap warga negara tanpa harus mengabaikan potensi lokal yang bersifat khas dan mengandung beragam nilai luhur. Justru dengan belajar bahasa Indonesia, diharapkan peserta didik dapat lebih dekat dengan akar budaya yang diwariskan secara turun temurun, termasuk yang berkaitan dengan hubungan manusia dengan lingkungan. Pembelajaran bahasa Indonesia yang menyajikan teks bermuatan pendidikan lingkungan dengan latar belakang budaya nasyarakat daerah memunhkinkan peserta didik lebih mudah dan lebih menikmati belajar karena berhadapan dengan topik atau masalah yang bersumber dari lingkungannya.

Tulisan ini diharapkan dapat menginspirasi para pendidik untuk menyajikan materi pelajaran dengan memanfaatkan beragam teks berbasis kearifan lokal daerah, terutama yang memuat pendidikan lingkungan. Sekolahsekolah di lingkungsn masyarakat Osing termasuk yang berpotensi menerapkan pemanfaatan teks-teks dengan ketentuan tersebut. Cukup tersedia sumber yang dapat dimanfaatkan, terutama yang terdapat pada berbagai situs dan laman. Tinggal diperlukan komitmen dari para pendidik untuk memodifikasi sumbersumber yang ada menjadi bahan ajar yang siap disajikan.

\section{DAFTAR RUJUKAN}

Al-Anwari, Amirul Mukminin. (2014). Strategi Pembentukan Karakter Peduli Lingkungan Di Sekolah Adiwiyata Mandiri. Dalam Ta'dib, Vol. XIX, No. 02. Edisi. http://jurnal.radenfatah.ac.id/index.php/ tadib/article/view/16 Diakses tanggal 15 November 2018.

Anggraini, Purwati dan Tuti, Kusniarti. (2017). Character and Local WisdomBase Instructional Model of Bahasa Indonesia in Vocational High Schools. Journal of Education and Practice Vol.8, No.5, 2017. https://files.eric.ed.gov Diakses tanggal 20 November 2018.

Armawi, Armaidy . (2017). Kajian Filosofis Terhadap Pemikiran Human- Ekologi Dalam Pemanfaatan Sumberdaya Alam. Dalam Jurnal Manusia dan Lingkungan. Copyright $\quad$ (c) 2017. https://jurnal.ugm.ac.id/JML/article/ view/18474 Diakses 15november 2018.

Coyle, D. (2007). Content and Language Integrated Learning: Towards a Connected Research Agenda for CLIL Pedagogies. International Journal of Bilingual Education and Bilingualism, 10(5), 543-562. DOI: $10.2167 /$ beb459.0

Djaali, H. (1995). Peningkatan Kesadaran Lingkungan Melalui Penerapan Model Contoh Terpadu: Studi Eksperimen pada Masyarakat Rawan Lingkungan di Sulawesi Selatan. Dalam Jurnal IImu Pendidikan (Jilid 2 Nomor 1 Halaman 31-45).

https://www.researchgate.net/public 
Jurnal Belajar Bahasa, ISSN 2502-5864, E-ISSN 2503-0329

Volume 4, No. 1, Februari 2019

ation/307789981 Diakses tanggal 15

November 2018.

Goodman, Ken. (2005). What Whole in

Whole Language, 20 ${ }^{\text {Th }}$ Anniversary

Edition. Barkley: RDRBooks.

Hidayati, Deny. (2017). Memudarnya

Kearifan Lokal Masyarakat dalam

Pengelolaan Sumberdaya Air. Jurnal

Kependudukan Indonesia vol 11

nomor 1 juni 2016. Halaman 39-48.

https://www.researchgate.net/.../31956

7954 Diakses tanggal 15 November 2018.

Kementerian Pendidikan dan

Kebudayaan. (2017). Permendikbud

Nomor 24 tahun 2017. Jakarta:

Kemendikbud.

Kementerian Pendidikan dan

Kebudayaan. (2017). Bahasa

Indonesia SMP/MTs Kelas VII.

Jakarta: Kemendikbud.

Mickan, Peter. (2015). Text-Based

Teaching: Theory and Practice.

https://www.researchgate.net/

publication/265011929 Diakses

tanggal 28 November 2018.

Rukiyati. (2017). Pendidikan Moral di Sekolah. Jurnal Humanika Th XVII, No.

$1 \quad$ September 2017.

https://researchgate.net Diakses tanggal 20 November 2018.

Santoso, Dian Kartika dan Wikantyoso,

Respati. (2018). Pengembangan

Agrowisata Apel Berbasis Kearifan

Lokal Di Poncokusumo. Local Wisdom,

$10 \quad$ (1): $1-6$.

https://www.researchgate.net/public

ation/327903484 Diakses tanggal 20

November 2018. 